\title{
Sin Ŏnjun (1904-1938) and Lu Xun's Image in Korea: Colonial Korea's Nationalist Transnationalism
}

\section{VLADIMIR TIKHONOV}

Throughout the Japanese colonial period, Korea's reading public paid close attention to Chinese revolutions against Japanese and Western empires. Korean nationalists viewed China's revolutionary struggles as important for liberating Korea from Japan, a stance that reveals a transnational basis of Korean nationalism in the colonial era. One such nationalist was Sin Ŏnjun (1904-38), Tong'a Ilbo's Shanghai-based correspondent, who played a critical role in conveying the momentous events in contemporary China to colonized Koreans. Drawing on Sin's example, this article shows how Sino-Korean transnationalism constituted Korea's left-wing, progressive nationalism in the 1930s. Although Sin Ŏnjun was a nationalist rather than a communist, he highlighted the communist struggles in China in his dispatches. He saw communism as the only viable way of solving China's internal and external problems, although he, at the same time, disapproved of Chinese communists" "terrorist methods." This article argues that this position also reflected his stance in favor of a broad communist-nationalist alliance in the Korean independence movement. He saw Korea's liberation agenda as closely related to the revolutionary events in China, thus accomplishing a synthesis between Korean nationalistic and social aspirations and an East Asia-wide transnational paradigm of a universal emancipatory struggle.

Keywords: Chiang Kai-shek, colonialism, communism, Guomindang, Japan, journalism, Korea, Lu Xun, Sin Ŏnjun, Tong’a Ilbo

\section{Introduction: Lu Xun's Interview, ReALity ANd Fiction}

I have long heard the name of Lu Xun, 'the great Oriental writer' born in China. However, I never had an opportunity to meet him. My impression of him, based on my reading of his writings and novels, was that of a cold-blooded or perhaps eccentric person. He appeared to be an odd surgeon who, armed with a surgical knife, cuts out, without any anesthesia, the affected part of any person he meets (of course, all of them are indeed patients). However, his cold-bloodedness and strangeness notwithstanding, his surgical skills are sharp, daring and based upon rationality. His surgery is pitiless, but one feels overjoyed—albeit in pain—when his surgical knife pierces [the flesh]. I was long curious about this eccentric and wished to meet him once....

Vladimir Tikhonov (vladimir.tikhonov@ikos.uio.no) is Professor of Korean and East Asian Studies in the Department of Culture Studies and Oriental Languages at Oslo University. 
He lived in hiding, using a secret room in the house of one of his Japanese friends on the North of Sichuan Road, no. 000. First, I asked him for a personal interview through a letter. He replied to me saying that he hides [from the authorities] and may suffer violence [at their hands], and thus asks me to narrate my requests in writing. I asked him for a secret interview once again, however, and we arranged our secret meeting on the 22nd [of May]. That is how I managed to meet the great writer, Lu Xun, whom I always wished to personally encounter...

[Lu Xun] did not shave. It looked as if he never cared about adorning his body at all. His sleeping mat was also of a plain Chinese style.... Even his cooking utensils were of the kind the Chinese poor are accustomed to using, without a single one of any visible value. The whole of his life was a model of a proletarian [life]. He did not limit himself to appealing to the proletarian class by his mouth or brush-his body, his life were also of a proletarian kind. The royalties he received from a variety of Shanghai bookstores, amount to two thousand yuan monthly; receiving in addition three or four thousand yuan in royalties for his translated books from various states of Europe and America, he counts as the highest-grossing Chinese writer. He could easily lead a luxurious life, but instead lives as a provincial peasant. He donates his whole income to the literary movement organizations....

I started our conversation with Chinese-style greetings, praising the literary talents [of my interlocutor]. He answered at once that he is not a man of letters. According to him, he simply accidentally came to wield his brush....

Question: You are being referred to as a humanist.

Answer: But I am absolutely against the humanists like Tolstoy and Gandhi. I advocate a fight.

Question: Who is the representative proletarian writer in the Chinese literary circles?

Answer: Ms. Ding Ling is the only proletarian writer. I cannot write authentic proletarian literature, since I hail from the petit-bourgeois class. I am simply a person on the Left....

I asked him about the liberation of the weaker nations. He answered: "Only after the world XX [revolution-V.T.] will be accomplished, the weaker nations will be liberated, I think." Then our subject-matter switched to fascism and Soviet Russia. He asked me about the situation in Korea. On having heard from me that books in Korean are becoming increasingly fewer and Korea's literature, or even culture in general, is being increasingly XX-ized [Japanized-V.T.], he opined that it is not something to view pessimistically at all. In Japanese or in Russian, it does not matter, he said, and added that he rejects the principle of 
national essence (guocui) and wishes [written] Chinese language to disappear in China and rather a language better than Chinese, be that English or French, to be popularized in China.... (Sin Ŏnjun 1934)

$\mathrm{T}$ HE TEXT ABOVE Is a collection of the fragments from an article by colonial-era Korea's mainstream “cultural nationalist” daily Tong’a Ilbo’s 東亞日報 Shanghai and Nanjing correspondent, Sin Ŏnjun (1904-38), incorporating his May 22, 1933, interview with Lu Xun (1881-1936), then and now acknowledged in Korea as the most influential modern Chinese writer. Starting in the early 1920s, Lu Xun made the acquaintance of several prominent Korean intellectuals sojourning or living in China, most of them anarchists and anti-colonial activists. ${ }^{1}$ Aside from Korean intellectuals, he was also popularized in colonial-period Korea by Karashima Takeshi (1903-67), a Chinese literature professor at Keijŏ Imperial University and Lu Xun's close personal acquaintance since the mid-1920s (Hong 2011). However, the interview found in Sin's article is the only known official interview ever given by the Chinese literary genius to a Korean press outlet. For a student of colonial-era Korea's intellectual history, it is interesting not because of what it tells us about Lu Xun's life or opinions, but rather because of what it reveals about the agenda of Sin Ŏnjun, the Korean journalist who managed to interview the titan of China's modern literature three years before his interviewee's passing and five years ahead of his own demise.

In fact - as a South Korean scholar of Chinese literature, Kim Sijun (2002), persuasively demonstrates - much of the content of Sin's article may be regarded as problematic. In May 1933, Lu Xun did not live in hiding, his rather complicated relationship with Guomindang 國民黨 (the Chinese Nationalist Party) authorities notwithstanding. His lifestyle differed a lot from that of China's "provincial peasants" or "proletarians" - he lived in a European-style redbrick house (No. 9, Continental Terrace, now the Lu Xun Former Residence Museum) where, according to his son's remembrances, the family used two floors, together with their nurse and maid. Lu Xun did regularly shave (it is clearly shown on his Shanghai-period photos) although we certainly have no ways to know whether he shaved on that particular day when he met Sin. His monthly income, calculated from his diary records, amounted to about four to six hundred yuan, certainly not "two thousand" or "three or four thousand." He did not donate "the whole" of his income to literary groups, although he did generously support a number of leftist writers and publications (Shi 2011): the diary records testify to the fact that he also had to support his family, as well as his mother and first wife (Zhu An), who lived in Beiping (today's Beijing). Even more importantly, Lu Xun, a co-founder of the League of Left-Wing Writers (Zhongguo Zuoyi Zuojia Lianmeng 中國左翼作家聯盟), would hardly ever have agreed with being characterized as a "humanist," even with a proviso on the "advocacy of fight." "And, as a national writer, he could hardly have voiced a wish for English or French to supplant Chinese in China, or for Japanese to substitute for Korean in Korea (although his thoughts on the possible desirability of having Chinese Latinized are well known) (Kim Sijun 2002). In a word, Sin Ŏnjun’s “interview” with Lu Xun, as well as Sin's record of visitation to the great writer, should be treated as a semi-literary

${ }^{1}$ On Lu Xun's Korean network, see Kim Sijun (1997).

${ }^{2} \mathrm{On}$ Lu Xun's understanding of the revolutionary mission of literature, see Davies (2013, 228-81). 
narrative rather than a journalistic correspondence, most likely reliant on certain real facts and life impressions, but significantly modified on the basis of Sin Ŏnjun's—or perhaps his editors'- own agenda.

That the meeting in question actually took place is difficult to doubt. Lu Xun's carefully kept diary contains a number of Tong'a Ilbo-related records for mid-May 1933. The great writer received two letters from the newspaper on May 16 and 18, and sent two letters to his Korean interlocutors on May 17 and 19 ( $\mathrm{Lu} \mathrm{1981,} \mathrm{15:80).} \mathrm{It} \mathrm{may} \mathrm{be}$ assumed that Sin Ŏnjun acted on behalf of Tong'a Ilbo, exchanging letters with the Chinese luminary in preparation for the meeting. Whereas Sin's letters are not extant, Lu Xun's two letters are known and published. In the letter sent to his Korean correspondent on May 19, Lu Xun suggests to him that they meet on May 22 at 2:00 p.m. in the bookstore kept by his close Japanese friend, Uchiyama Kanzō (1885-1959) (Liu 2001, 2:661). It must be assumed that the interview took place then-somewhere in the bookstore's vicinity, maybe in Uchiyama's house (the "house of one of his Japanese friends" may have originated there) or possibly in the storage room for Lu Xun's books, where the writer also often worked, not very far away (Hong 2011).

However, Sin Ŏnjun's record of what his celebrated interlocutor said appears to be at least severely redacted. Some of Lu Xun's suggested “answers” are plausible, but in a much less categorical or emphatic form. For example, Ding Ling, a Chinese Communist Party member since 1932, was indeed undergoing a transition to revolutionary literature in the early 1930s (Feuerwerker 1982, 52-89). However, she certainly was not "the only proletarian writer" in China. That was something Lu Xun, as the co-founder of the League of Left-Wing Writers, must have known for sure. So, why did Sin Ŏnjun deem it necessary to subject the answers by the renowned Chinese writer to such "creative editing" and, in addition, to portray him as somebody he never was: a revolutionary ascetic living (in hiding) a life of a "proletarian kind" and sacrificing every yuan of his income to the revolutionary cause? Why had Lu Xun's doubtlessly internationalist stand been exaggerated into an almost absurd-sounding acquiescence to China's improbable conquest by the "English or French" language or to Japan's creeping linguistic assimilation policy in Korea-which Lu Xun, a convinced anti-imperialist, had no reasons whatsoever to support (Hong 2008)?

To answer the questions above, we have to investigate the nature of the narrative of China and the Chinese revolution that Sin Ŏnjun, doubtlessly one of the key intermediaries between the public spheres of Republican China and colonial-era Korea, had been constructing before and during his six years of tenure as Tong'a Ilbo's correspondent in Shanghai and Nanjing (1929-35). As a background, we have to examine first the general state of China-related discourses in the Korean press by the time Sin Ŏnjun started his career as Tong’a Ilbo's China expert. Clarifying Sin Ŏnjun's agenda in constructing his China narrative, as well as the essential features of this narrative, may contribute to a deeper understanding of colonial-era Koreans' perceptions of China amidst the revolutionary turmoil, and the hopes and fears that the Chinese revolution generated in the minds of its Korean observers. It may also contribute to the general understanding of the process of framing-the process through which reality is being reproduced and represented by journalists.

Framing by the media is a complicated process influenced by the wishes, explicit and implicit, of the media owners, but also simultaneously by the educational and ideological background of the journalists themselves. Some of their agendas are shared by the 
owners and managers of the media, and some are not. While framing public interest issues, journalists also have to interact with the public, taking into consideration its own reference frames and perceived interests while simultaneously attempting to channel or shift them in a given direction (Reese 2001). All these factors certainly came into play when Tong'a Ilbo's China correspondent had to frame China for the consumption of the (educated) Korean reader in the late 1920s-30s.

In addition, as I will attempt to demonstrate, Sin Ŏnjun, a Korean nationalist activist who wrote for the heavily censored (Robinson 1984) and significantly commercialized (Pak Yonggyu 2015, 80-115) colonial-era press, might also have wanted to use China as a convenient foreign topic for discussing the popular, high-demand issues that censorship was making difficult to discuss domestically-namely, the issues of revolution and socialist ideology. In a situation where an interview with a Korean revolutionary had a good chance of being deleted by the Japanese censors, Sin Ŏnjun could utilize a highly exaggerated picture of Lu Xun as a revolutionary writer to discuss the otherwise sensitive issues of the pros and cons of the socialist struggle with his readers.

\section{The Tradition of Reporting on China in Colonial-Era Korea}

As prolific a writer on China as he was, Sin Ŏnjun certainly was not the first Korean newspaper correspondent in the China field. As early as in 1920, Tong'a Ilbo sent one of its founding journalists, Chang Tŏkchun (1892-1920), to Beijing, to report on the 1920 Zhili-Anhui War. Chang's very detailed report, complete with interviews with some of the main protagonists of the conflict, was serialized in Tong'a Ilbo in August 1920 (Chang 1920). As a rule, the China correspondents of Tong’a Ilbo or Chosŏn Ilbo 朝鮮 日報 were highly educated social or political activists of some sort with agendas of their own, often relatively independent from that of their own newspapers' editorial offices. For example, in 1924 Tong'a Ilbo sent Cho Tongho (1892-1954), then its journalist, to cover the Second Zhili-Fengtian War. Cho was, however, no ordinary newspaperman. A graduate of Jinling (Nanjing) University and a former journalist with the Chinese Guomindang press and Tongnip Sinmun 獨立新聞, the Shanghai-based publication of the Korean Provisional Government (founded in 1919), Cho was an important pro-independence activist of leftist persuasion, who was then instrumental in founding the underground Korean Communist Party in 1925 (Yi Hyŏnhŭi 1992, 58-66, 174-99, 258-72).

Indeed, Cho was not the only member of the communist milieu to be sent on assignment to China. Yet another prominent communist, Kim Chun'yŏn (1895-1971), who was to become the secretary general (ch'aeg’im piso 責任秘書) of the underground Korean Communist Party in 1927 (Kim and Kim 1986, 3:209-15), produced some reporting on China on his way to Moscow in 1925; he was to become Chosŏn Ilbo's first-ever correspondent there (Kim Seho 2014, 76).

Thus, from the beginning of the 1920s, "reporting on China" was an activity not infrequently associated in Korea with some sort of radical beliefs. After all, the revolutionary possibilities of Korea's giant neighbor to the west were what attracted most of the would-be reporters from Korea (Tikhonov 2015, 104-30). On this point, there were hardly any recognizable differences between the reporters from Tong'a Ilbo and Chosŏn Ilbo, although more generally, the tones of their foreign policy reporting were 
far from being completely identical. The two newspapers relentlessly competed with each other, the latter positioning itself to the left relative to the former. It demonstrated more of sustained positive interest vis-à-vis the USSR than Tong'a Ilbo, and was strongly denouncing imperialist states' inexorable downslide towards a new world war-and especially the actions of the fascist powers of Europe in the mid-1930s. On China, however, both papers were mostly in agreement, both wishing China to become a stronger, more unified state and have the plight of its disadvantaged majority alleviated through the implementation of more progressive policies. A certain role in providing the sympathetic coverage for the Chinese revolutionary efforts was-as I have mentioned above-played by the reporters in both papers belonging to the underground communist groups (they even had their own unofficial workplace cell at Chosŏn Ilbo) or generally influenced by socialist currents (Kim, Pak, and Kim 2008, 51-54, 61-73, 125-35).

The majority of China correspondents from Korea in the 1920s were, however, progressive nationalists rather than communists-independence-oriented nationalism too being considered, of course, a radical belief in colonial Korea. A typical example would be Yi Sangch'ŏl (1893-1979), a Japan-educated journalist who made an illustrious career as a moderate oppositional politician in South Korea after decolonization in 1945. Sent by Chosŏn Ilbo to cover the Second Zhili-Fengtian War in 1924, Yi distinguished himself by managing to interview Sun Ke (1893-1971), a son of Guomindang founder Sun Yat-sen (1866-1925) and himself a prominent Guomindang politician. The Guomindang still was considered a potentially revolutionary force in 1924, and Yi's attention towards the Guomindang exhibited his positive interest towards Chinese revolution in general. In 1925, Yi had troubles with the Japanese police due to an article in which he-presciently_-suggested that the Soviet Union might be helpful in securing Korea's independence. Still, he was no communist, positive interest in the USSR or certain sympathies towards the communist movement in general being-as we will see in Sin Ŏnjun's case as well—rather widespread among the colonial intelligentsia of a generally progressive and nationalist bent (Chosŏn Ilbo Saryo Yŏn'gusil 2004, 129-34).

Yet another Korean journalist who lived in and wrote on China for the monthly Kaebyǒk in the early 1920s, Yi Tong'gok, appears to have shared the belief in the future intervention by the Soviet Union (and the United States) to end the Japanese expansion in continental East Asia (first China and then, by extension, Korea). A nationalist, likely with connections to Korea’s indigenous Ch’ŏndogyo 天道敉 religion, Yi was also deeply interested in the development of China's progressive new culture, symbolized by the famed journal New Youth (La Jeunesse, Xin Qingnian, 1916-26) (Han 2005). Lu Xun-like some of the founders of the Chinese Communist Party-was initially a part of the milieu around this journal.

Until its counter-revolutionary turn in 1927 and even for some years after that, the Guomindang attracted the sympathies of the Korean correspondents as well. After 1927, however, these sympathies were often mixed with rather critical attitudes towards Chiang Kai-shek's (1887-1975) increasingly stiff anti-communist policies. These attitudes were illustrated by the China reports by Yi Kwan’yong (1894-1933), a Chosŏn Ilbo correspondent sent to China in 1928 as the Guomindang’s northern expedition was being completed and China's long-awaited reunification was attracting the keen attention of Korean observers. Yi Kwan’yong - an intellectual who possessed a doctoral degree in 
philosophy from Zürich, a rare occurrence in colonial-era Korea-was, not unlike Sin Ŏnjun, combining journalism with nationalist activism of a nonsocialist but still quite radical bent. He was a founding member of the Sin'ganhoe 新幹會—an approximately 49,000-person-strong organization that operated in Korea in 1927-31 on the basis of cooperation between communists and nationalists (Yi Kyunyŏng 1993). It was initially modeled on the Guomindang, which, until 1927, included communists. Yi was even imprisoned by the Japanese authorities for a year and a half for his activities (Chosŏn Ilbo Saryo Yŏn'gusil 2004, 124-29). Yi’s reporting on China-not unlike Sin Ŏnjun's, as we will see later-was closely related to his own political agenda: wishing communists and nationalists to cooperate in Korea, he had solid reasons to want to see the Guomindang provide a good example of such cooperation.

The events on the ground, however, did not develop to Yis liking. When Yi was touring China in the autumn of 1928, the split between the Guomindang and the Communists was more or less irreversible. The Sixth Congress of the Chinese Communist Party, convened in a village near Moscow (since the Guomindang's "white terror" would not allow such a gathering in China), acknowledged the failure of the coalition and oriented the party towards the new struggle under the conditions of illegality, with the aim of "acquiring hegemony among the masses" (Sheng 2009, 210-20). Encountering the split of the erstwhile "united front," Yi understood it as a serious setback for China's revolution. As he saw it, the Chinese revolution was still far from complete. The bourgeoisie and the forces inside the Guomindang that the oligarchic capital supported were temporarily triumphant, but the underprivileged majority ("the working class and the peasants"), now organized and politically mobilized at the grassroots level, was hardly inclined to permanently accept its defeat. As Yi contended, the Guomindang leadership had to secure mass support from below in order to achieve its aim of completely freeing China from the legal shackles imposed on it in the form of unequal treaties and the like by the imperialist predators. To do this, Yi concluded, the Guomindang had to revert to Sun Yat-sen's original policy of an alliance with the Communists (Yi Kwan'yong 1928a). In his 1928 China reports, Yi mentions the Communists in a much briefer way than Sin Ŏnjun does several years later. However, Yi does refer to Hunan's Autumn Harvest Uprisings of 1927, as well as the Guangzhou Uprising (Canton Commune) of the same year as proof that communist influence was far from negligible-even inside the Guomindang's own ranks, as Yi emphasized (Yi Kwan'yong 1928b).

Yis positive attention towards the Chinese Communists was one of the precedents that might have influenced the tone of Sin Ŏnjun's China reporting. However, the views on Chinese affairs of the type Yi exhibited were also fairly widespread among the Korean journalists, including those of a nonsocialist nationalist persuasion. Yi's negative assessment of Chiang Kai-shek's hardline anti-communist policies was shared, for example, by Chu Yohan (1900-79), then the editorial chief of Tong’a Ilbo (Chosŏn Ilbo Saryo Yŏn'gusil 2004, 279-83), who would be later responsible for handling Sin Ŏnjun's reports from China. Chu-like Yi Kwan'yong, a Sin'ganhoe activist (Yi Kyunyŏng 1993, 306)—regarded Chiang Kai-shek's anti-communist coup as the beginning of a "reactionary turn" in the Guomindang’s politics (Chu 1928), although he otherwise viewed China's unification by the Guomindang in a positive way (Kim Seho 1999). The skeptical attitudes vis-à-vis the Guomindang’s hardline anti-communism enjoyed wide popularity in the Korean nationalist press milieu, and certainly influenced the 
ways in which Sin Ŏnjun perceived China’s contemporaneous conditions (Kim Seho 2014, 96).

\section{Sin Ŏnjun, the Chinese Revolution, And the Guomindang}

A native of P'yŏngwŏn County, Southern P'yŏng’an Province, Sin Ŏnjun graduated from the Christian Osan School (五山學校), known for an atmosphere of intense anticolonial nationalism. In 1923, assumedly under the lingering influence of the March 1, 1919, independence movement in Korea, Sin Ŏnjun joined the flow of nationalist and early socialist refugees heading for China. He is known to have studied English in Hangzhou and then entered Shanghai's Wusong National Zhengzhi University (Min 2000b). Studying in China was at that time one of the alternatives available for the nationalist Korean youth unwilling to submit to what they often referred to as "slave-like education" (noye kyoyuk 奴隷敉育) inside colonial Korea. ${ }^{3}$ As is mentioned above, Cho Tongho, one of Sin's predecessors as a Korean newspaper reporter in China, had studied in Nanjing already in the 1910s. Chu Yohan-who was to become Sin's boss as Tong'a Ilbo's editorial chief_-studied at Shanghai's Baptist Hujiang University, returning to Korea in 1924 (Yi Paeho 2002, 20). A practicing Christian, Chu was a member of the Young Korea Academy (Hŭngsadan 興士團), a nationalist group with Protestant roots (inspired, in part, by Masonic lodges) that had its Far Eastern Committee's headquarters in Shanghai (Yi Paeho 2002, 20-24); on Sin's participation in the same group I will elaborate further below.

Sin had already started to contribute to Tong'a Ilbo as a student. One of his earliest known publications there can be found serialized weekly in the March 27-April 6 issues of 1925. Ambitiously entitled “Personality and Education” (In’gyŏk kwa Kyoyuk 人格과 䍩育), the article discusses the shortcomings of a modern education, "based on mechanism and individualism," as well as socialization into the nation-state collectivity, and argues for "overcoming the gap between individual and society" (Sin Ŏnjun 1925) in a less alienated, more organic fashion, with education serving the aims of "personality improvement" rather than the objectives of state and capital. A freer personality, hopefully, was to develop a natural inclination toward contributing to the socio-cosmic entirety. Hardly an independent thinker at this stage, Sin Ŏnjun still makes clear his disagreements with the standard liberal-nationalist frame, and argues for more radical approaches. Judging by a fragment from Zhang Junmai (1886-1969) that he chose for translation and publication in Tong'a Ilbo in 1924, he was engaged at this stage in the search for a "scientific approach to the spiritual life." Zhang's text, which Sin Ŏnjun translated, was an attempt to classify different approaches to life based on their varied modes of drawing boundaries for one's personality (Zhang 1924). It looks as if "personality" was the centerpiece of Sin's philosophical and ideological searching at that point. However, some years later, the axis of Sin's interests definitively shifted to more social concerns: "class," rather than "personality," took the central stage.

${ }^{3}$ See the usage of this term, for example, in Sin Ch'aeho's famed Korean Revolution Manifesto (An 1979, 187-96). 
A longish article on China's labor issue, serialized December 14-15, 1927, for Tong'a Ilbo, was Sin Ŏnjun's first experiment with a socio-political analysis of China for Korean media. While this and other writings on China by Sin were often based on insufficient data and peppered with factual errors (Min 2000b, 21), this particular article is still interesting given its explicit aim to refute the myth of China's labor movement being either simply destructive "rioting" or an anti-foreign campaign. Instead, Sin Ŏnjun attempted to demonstrate that China's labor movement gradually politicized after May Fourth events in 1919 as activists were becoming painfully aware of the direct connection between low wages and abusive conditions in the foreign-owned factories and imperialist powers' political hold on China cemented through unequal treaties. The analysis Sin Onjun deploys comes rather close to the contemporaneous Marxist understanding of the effects that the imperialist penetration into semi-colonial and colonial markets and raw materials supplying areas were supposed to have on the nascent local proletariat. ${ }^{4}$ The latter was to suffer under the conditions of over-exploitation to guarantee the colonial extra-surplus extraction to the foreign entrepreneurs. It is also noteworthy that even the "reactionary" reluctance to follow the policies dictated by the Chinese Communist Party's Comintern (Communist International, 1919-43) on the part of a sizeable chunk of the Chinese working class is explained by Sin Ŏnjun as a continuation of the antiforeign nationalist pattern developed in the struggle against foreign exploitation (Min 2000a, 201-6).

Would this imply that Sin Ŏnjun developed sympathy for the Chinese Communists? A detailed analysis of the history and realities of the Chinese revolution that Sin Ornjun serialized in Tong'a Ilbo a couple of years later (June 5-17, 1929) demonstrates that his perspective on the Chinese situation was much more nuanced than simply "siding" with one of the sides of what had already developed into an open civil war between Guomindang Nationalists and Communists. In principle, not unlike Yi Kwan'yong (Kim Seho 2014, 104-6), Sin Ŏnjun saw the emergence of a strong, mass-supported central government that was able to break away from a dependency relationship vis-à-vis the imperialist powers and proceed with centralized developmental planning as the only hope for China. Still, according to Sin Ŏnjun, the Communists were still too weak and too devoid of broader popular support to assume the position of such a developmentalist central government. As a veteran South Korean Sinologist, Min Tu-ki (1932-2000) mentioned in his preface to a collection of Sin's writings that Sin saw the more progressive factions inside the ranks of the Guomindang as the best candidates for the national leadership (Min 2000b, 17) — as long as they would manage to further radicalize and ally themselves with China's "genuinely revolutionary classes" (the petit bourgeoisie, "workers' and peasants' masses," and students) and thus develop a broad support platform.

A good model could be the policies promoted by Turkey's Mustafa Kemal Atatürk (1881-1938), to whom Sin Ŏnjun devoted an article in a nationalist monthly journal, Tonggwang 東光, in 1931; Atatürk was chided for his dictatorial style, but praised for the ability to win mass support, break the chains of dependency on foreign capital, and develop national industries (Sin Ŏnjun 1931b). The Chiang Kai-shek government, as

\footnotetext{
${ }^{4} \mathrm{~A}$ similar frame of reference was deployed by Korean communists in their analyses of the socioeconomic conditions of colonial Korea (Sim 2015, 336-49).
} 
Sin Ŏnjun saw it, was moving at that time in a very different direction, developing an Italian-style fascist dictatorship but without that kind of pan-national support from both petit and large-scale bourgeoisie that Mussolini enjoyed. Chiang's clique relied upon the army, bureaucracy, and some sections of the Zhejiang capitalist oligarchy, and was hardly capable of proceeding with national development strategies with such a narrow support base. Following the tone of China-related articles by Yi Kwan'yong and Chu Yohan mentioned above, Sin Ŏnjun appears in this article strongly nostalgic about the bygone era of pre-1927 Communist-Nationalist cooperation; this sort of broad national alliance was, in his view, a necessary condition for a genuine revolution in China (Min 2000a, 212-32).

By the mid-1930s it was, however, clear that the Guomindang's "radical turn" was hardly to be realistically expected. In 1928, Yi Kwan'yong could still attempt to defend the Guomindang from the accusations of being a dictatorial, leader-centered organization (Kim Seho 2014, 97-98); by the mid-1930s, a bureaucratic dictatorship had become a reality (Tien 1972, 18-45). In a 1934 analytical article on the ideological developments among China's intellectuals (published in monthly Sintong'a 新東亞 in November), Sin Ŏjun defines Chiang Kai-shek as an aspiring fascist dictator who, however, was in no position to become a worthy imitator of Mussolini or Hitler due to China's semi-colonial status. Thus, Chiang was forced to search for allies among the stubbornly conservative, semitraditional gentry, reconfiguring his fascistic New Life Movement (Xinshenghuo Yundong 新生活運動) to the patriarchal Confucian dogmas still popular in this "feudal" milieu. ${ }^{5}$ In a semi-colonial society, as Sin viewed it, even fascism was bound to degrade into an attempt to revive a "reactionary feudal ideology." If the semi-colonial bourgeoisie was to attempt to adapt some elements of contemporary Western culture to China, this would be necessarily limited to "decadent hedonism, opportunism, individualism and the [social] evils of debauchery: 'eroticism', 'love', 'café' and 'dances." Such an attempt would only precipitate a ferocious ultra-conservative reaction. The only way out of the vicious circle of mindless borrowing of Western consumerism and "feudal" revivalism was, according to Sin Ŏnjun, a serious engagement with "proletarian thought," which was quickly penetrating down into the "people's masses," as "villages were turning Red, arming themselves and establishing Soviet governments, bravely opposing the Nanjing regime as Communist organization members." Many intellectuals, as Sin Önjun saw it, quietly understood the inevitability of the "proletarian solution," but were too opportunistic and cowardly to openly stand on the leftist platform in the face of censorship and fierce repression. And these few who dared to stand up to the suppression would have to "ascend the guillotine, go to prison, or find their refuge abroad or inside the foreign concessions" (Min 2000a, 155-60). Rather than a progressive turn by the Guomindang, a "proletarian revolution" appeared now to Sin Ŏnjun as a plausible solution for the "Chinese question."

Sin Ŏnjun's sympathetic attitude towards China’s Communists did not mean, however, that he ignored other ideological and political forces critical of or resistant to the Guomindang dictatorship. In a society Sin Ŏnjun aptly characterized as deeply grounded in largely premodern social relationships and ideological forms, especially in the countryside, "revolution" could mean much more than simply a political struggle.

${ }^{5}$ On the New Life Movement, see Dirlik (1975). 
Hu Shi (1891-1962) — as described by Sin Ŏnjun in a detailed article for Tonggwang in August 1931 — was an archetypic cultural revolutionary. Indeed, Hu was a well-known personage among the Korean intellectuals already in the 1920s-Tong'a Ilbo asked him to send his New Year greetings and published these greetings in its New Year issue for 1925 (Hu Shi 1925). According to Sin Ŏnjun, Hu’s advocacy of empirically based truth was highly instrumental in breaking from the millennia-long "tyranny of the classics." Hu Shi's concurrent advocacy of literary and language reforms also drew Sin Ŏnjun's interest: he included comprehensive summaries of $\mathrm{Hu}$ Shi's main writings on these issues in his article. The Korean journalist obviously admired Hu Shi's penchant towards searching for East Asia's putative native "sprouts" of modern thought as well: he also summarized at length the main reasons why $\mathrm{Hu}$ Shi came by the end of the 1920 s to consider Dai Zhen (1724-77)—a Qing iconoclast known for his rejection of neoConfucianism and his emphasis on evidence-based truths as well as on human individuality and desires - as one of the pioneers of East Asia’s modern thought. ${ }^{6}$

However, as Sin Ŏnjun reported, the tireless defender of intellectual freedom and modern culture had his options severely restricted by the Guomindang’s "autocratic regime," which deprived him of teaching opportunities and constantly threatened him with even harsher sanctions (Min 2000a, 160-70). ${ }^{7}$ Hu's intellectual revolution was obviously powerless to break the grip of the Guomindang's political reaction. Sin Ŏnjun was seemingly fascinated with another Chinese non-communist intellectual, Li Shizheng (1881-1973), one of China's pioneering anarchists. In an article on him in Tonggwang in February 1931, Sin Ŏnjun mentioned with apparent approval his efforts to assist the Nanjing government in unifying China; however, he also noticed the obvious contradiction between Li's cozy ties with Chiang Kai-shek and his professed anarchist beliefs, as well as his declared antipathy towards assuming any governmental posts (Min 2000a, 170-79). Anarchists - whose hostility towards communism and "dictatorial" Soviet Russia Sin Ŏnjun was keenly aware of (Min 2000a, 176) — could hardly rival communists in the matters of popular revolutionary mobilization, and were too compromised by their connections to the Guomindang regime.

\section{Sin Ŏnjun And the Chinese Communist Movement}

Sin Ŏnjun's reporting on the Chinese Communist Party’s battles against the Guomindang was perhaps the single most important source of information on the radical developments in contemporaneous China for average Korean readers, who were otherwise denied access to foreign or underground (uncensored) publications. In fact, it was in one of the Shanghai dispatches, presumably sent by Sin Ŏnjun (his authorship is assumed, since he was Tong'a Ilbo's correspondent in Shanghai and Nanjing at the point when the dispatches were sent and published in the same paper) that Mao Zedong's name makes one of its first appearances in the history of the colonial-era Korean press. This 1929 dispatch described "land revolution"-radical land redistribution attempts—endeavored by "Mao Zedong's Communist Army" in the base areas of

\footnotetext{
${ }^{6}$ On Hu Shi’s understanding of Dai Zhen, see Hu Minghui $(2015,4-5)$.

${ }^{7}$ On Hu Shi's conflict with the Guomindang in the early 1930s, see Zarrow $(2005,263-65)$.
} 
Jiangxi (Sin Ŏnjun 1929). A December 31, 1929, article outlining China’s political situation dealt with the "Communist activities" in rural Jiangxi, Guangxi, Fujian, and Hunan as increasing, and noted Communist efforts in organizing workers and peasants. At the same time, Sin Ŏnjun maintained a certain critical distance, noticing, for example, that a large proportion of the "Communist troops" consisted, in fact, of local bandits and governmental army deserters (Min 2000a, 294-95).

In a later dispatch describing the Chinese Red Army's situation in Jiangxi, Sin Ŏnjun mentions both the unparalleled discipline and bravery of the Communist troops and their outdated weapons; he characterizes Mao as "China's Stalin" and sympathetically describes his background as the Communist Party's expert in agrarian issues (Sin Onjun 1931a; the authorship is assumed since the dispatch is attributed to Tong'a Ilbo's "Nanjing correspondent") but also makes a point of mentioning Mao's contenders inside the Communist Party. In the late 1920s, the main contender was, arguably, Chen Duxiu (1879-1942), one of the party's founders expelled in 1929 from the party for his increasing unwillingness to toe the Comintern's line, which, as he felt, led the party to the debacles of 1927-28 (Lee 1983, 185-96). In a 1930 article on China's proletarian movement, Sin Ŏnjun cites at length Chen's “Trotskyist” statement opposing Stalin's "opportunistic and bureaucratic" leadership as well as the party's current emphasis on "reckless rioting" in the countryside. In the same article, however, he approvingly cites also the Communist Party's twenty-nine-point-long "demands." Some points are omitted, but the demands for minority nationalities' "self-determination," gender equality, land redistribution, and workers' control over factory production are duly mentioned (Min 2000a, 336-39). It looks as if, retaining critical distance towards certain aspects of the current Chinese Communist movements, Sin Ŏnjun still viewed it as a possible alternative to a "fascist" dictatorship unable to break away from the semi-colonial dependency yoke.

The critical voice discernable in Sin Ŏnjun’s pioneering description of the Chinese Communist movement for the Korean public is not entirely dissimilar with the critical statements by Chen Duxiu that Sin Ŏnjun himself cited. In 1930-32 Tong’a Ilbo articles specially dealing with China's Soviet areas, Sin Ŏnjun mentions the "terror" tactics of the physical liquidation of the "class enemies" employed by the Communists, as well as controls over daily life, forced "Communist education," obligatory participation in public meetings, requisitions of valuables and grain from richer families, and involuntary conscription into the ranks of the Communist troops. Sin Ornjun notes with regret that the residents of the Soviet areas appeared to "lose their freedom"; at the same time, he also describes the enthusiastic reception the land redistribution measures and grain relief for the poorest met among the landless and poorer peasantry (Min 2000a, 34043, 484-88). That the Communist revolution was anything but liberal seems to have anguished the otherwise sympathetic Korean observer; he had, however, little doubt about the radicalism of the changes the Communists were to bring, as well as the level of popular support for them on the very bottom of China's social ladder. According to his 1933 observations, the Red Army had been continuing to grow, up to the level of an approximately 500,000-strong force, on the strength of popular support and sympathy in the rural areas; Chiang Kai-shek's ability to "suppress" it was severely limited, especially given the unfolding of the Japanese aggression since Japan's invasion of Manchuria in 1931. With the growing crisis of Guomindang authority, an alliance between the 
Communists and the broad middle-of-the-way forces Sin Ŏnjun termed "leftist nationalists"- the Young China Party, Zhang Junmai's China Democratic League, or the "leftwing Guomindang's Sun Ke and Chen Mingshu (1889-1965)"-could, according to Sin Ŏjun, seriously threaten Chiang Kai-shek’s dictatorship with a "new revolution" in the case that a humiliating surrender to the Japanese demands would deal a blow to Chiang's nationalistic legitimacy (Min 2000a, 78-79, 86-87).

The Communists, whatever their failings might have been, embodied, in Sin Ŏnjun's analysis of the early 1930s, China's revolutionary future. By contrast, Chiang's attempts to destroy them were, again in Sin Ŏnjun’s 1933 analysis, largely sponsored by the Shanghaibased Zhejiang financial clique in an attempt to secure its investments in the inland real property threatened by the Communist land reforms; ${ }^{8}$ the same group of financiers, deriving its profits more from speculation rather than productive investments, was behaving “anti-nationally," opposing a defensive war against Japan's aggression out of a fear of losing money due to the switch to a command war-time economy (Min 2000a, 529-33). In an environment where nationalist legitimacy and popular support-based on an effective realization of what the "masses" could recognize as distributive justice (land reform, etc.) - provided the only lasting foundation for a political success, Communists, rather than the Guomindang, looked like a more promising political force in the long term to the Korean observer.

However, as Soviet areas of China's interior were "pacified" by Guomindang troops and the Communists had to begin their year-long Long March in October 1934 (Yang 1990), Sin appears to have lost much of his interest in the movement, which, at that point, looked like a spent force. In his article on East Asia's — and particularly China's-political situation published by Tong'a Ilbo on January 1, 1935, he characterizes the Communist troops' march westward as the final defeat of the Chinese Communist movement. The Guomindang, according to Sin's analysis at this point, had succeeded in establishing political control over most of China and unifying its own ranks; it was now the Guomindang's task to defend China against imperialist predations (Min 2000a, 584-86). While Sin's enthusiasm about the Chinese Communist movement visibly ebbed in the autumn of 1934, on having witnessed what he regarded as the Communists' crushing defeat, this enthusiasm was palpable in his reports from China before that point. With the benefit of hindsight, we may conclude that the close attention Sin Onjun paid to the Chinese Communists was indeed vindicated by subsequent historical events. It is hard not to admire the analytical aptitude Sin Ŏnjun demonstrated in discerning and describing the Communists' winning formula - the combination of antiimperialist nationalism and populist distributive policies with highly effective and popular leadership, which appeared trustworthy against the background of what Sin Onjun justly portrayed as Chiang Kai-shek's corrupt and ineffective dictatorship with clear fascistic connotations, but a catastrophically narrow basis of support. What was, however, the background of Sin Ŏnjun's keen interest in China's communist movement?

${ }^{8}$ On the Zhejiang “financial clique," see Goodman (1995, 258-305). 


\section{Sin Ŏnjun's China Reporting and the Right-Left Cooperation in Korea}

Contrary to what a reader might surmise after browsing Sin Ŏnjun's very unflattering descriptions of Chiang Kai-shek's policies — with frequent use of such epithets as "fascistic"-and his much more sympathetic narrative of the Communist struggles, Sin Ŏnjun was in fact no communist himself. He was indeed a nationalist, a ranking member of the Young Korea Academy (Hŭngsadan). The Young Korea Academy, as is mentioned above, was a well-known nationalist group with its headquarters in the United States, led by An Ch'angho (1878-1938), one of modern Korea’s best-known moderate Christian nationalists. ${ }^{9}$ An Ch'angho, however, was no anti-communist; on the contrary, he had been working since mid-1925 to unify both leftist and nationalist forces on a platform that would include Korea's independence and building a socially engaged state that owned the key production facilities. A blueprint of such a broad alliance was suggested by the united front between the Guomindang and the Chinese Communists, the effectiveness of which An Ch'angho, who resided mostly in China throughout the 1920s, could witness himself. A blow to his plans was dealt by a breakdown of the Guomindang-Communist alliance in 1927; however, even after that, on January 25, 1930, An Ch'angho was able to establish the Korean Independence Party (Han'guk Tongniptang 韓國獨立黨), headquartered in Shanghai, which proclaimed the development of right-left cooperation as its major task. The political platform An Ch'angho had developed by that point, the so-called taegongjuŭi 大公主義 (Great Public [Good] Principle), was in essence a socialdemocratic program that combined the promise of a democratic state with a belief in a largely state-guided economy and distributive justice (Yi Myŏnghwa 2002, 264-92).

The contradictions between left and right-which An Ch'angho tried to overcome in the name of the joint anti-imperialist front-were indeed among the key issues that Korea's nascent modern civil society had encountered since the early 1920s. Following the success of the Russian October Revolution in 1917, socialist ideas started to gain popularity inside Korea in the early 1920s, being introduced through the tireless efforts of Russia- and China-based revolutionary exiles (mostly sponsored by the Comintern) as well as by Koreans who studied in Japan and came into contact with radical ideologies there. Given the dire conditions of Korea's underprivileged majority, socialism could be expected to find a fertile environment for growth there. The first socialist cells were already consolidated by 1922-23 inside the mass-based national organizations, the Korean Labour Fraternal Organization (Chosŏn Nodong Kongjehoe 朝鮮勞動共濟會) and the Youth Federation (Ch’ŏngnyŏn Yŏnhaphoe 青年聯合會) (Scalapino and Lee 1972, 49-55). By 1923, socialists' differences with the preexisting national movement were made official: the socialist-influenced Youth Organizations' Congress (Ch’ŏngnyŏndang Taehoe 靑年黨大會) issued a declaration proclaiming a non-class society, to be achieved through the ways of workers' and peasants' “organizational training” (a euphemism for class struggle), its objective. It also strongly criticized Tong'a Ilbo, calling even for its boycott. Koreans' ethno-national interests, as formulated by Tong'a Ilbo nationalists, were found to be vastly dissimilar to the needs of the "proletarian masses" (Kim Tongmyŏng 2005, 249-52). Although the underground Korean Communist Party, founded in

\footnotetext{
${ }^{9}$ See a report to the Young Korea Academy's Far Eastern Committee that mentions Sin's name in Hŭngsadan (1929); see also Yi Myŏnghwa (2002, 402-3).
} 
1925 on the basis of the more orthodox Tuesday Society (Hwayohoe 火曜會) faction, and other communist factions were instructed by the Comintern to seek a united front with more militant nationalists, the attempts at such cooperation almost always sparked heated debates between diverse communist groupings, which tended to differ on how reactionary or progressive divergent nationalist factions were (Chŏn 2006, 341-69). In colonial settings, left-right cooperation for the sake of anti-colonial struggle was direly needed, but it was never easy. The rightists often bemoaned the "class extremism" on the left while demonstrating little sympathy towards workers' or tenants' strikes, and the leftists tended to reciprocate with mistrust and antipathy (Pak Ch'ansŭng 2006, 286-99).

It appears likely that Sin Ŏnjun, who functioned as An Ch’angho's informal secretary in issues related to China and liaised with prominent Chinese politicians on An's behalf (Yi Myŏnghwa 2002, 402-3), might have attempted to convey the importance of the leftist mass movement-using China's Communists as a case in the point-to the mostly nationalist readership of Tong'a Ilbo in order to cement right-left cooperation inside colonial Korea. As is mentioned above, a joint right-left organization, Sin'ganhoe, with an approximately 49,000-strong membership, operated in Korea in 1927-1931 on the basis of cooperation between communists and independence-oriented nationalists (Yi Kyunyŏng 1993), and Sin’s article could be intended as reference material on communism outside of Korea for Sin'ganhoe's nationalist members. In fact, thirteen of about eighty core followers of An Ch'angho inside colonial Korea who were members of Suyang Tong'uhoe 修養同友會 (Fraternal Society for Self-Cultivation, 1926-37), the Young Korea Academy's sister organization inside the colony, chose to participate in Sin'ganhoe (Yi Hyŏnju 2003), together with thousands of less prominent nationalists who saw independence or, at least, the joint struggle against colonial oppression and discrimination eventually leading to the goal of independence, as the first priority for both left and right. Sin Ŏnjun's correspondences were most likely aimed for these activists and national movement supporters.

Doubtlessly, Sin Önjun was first and foremost an observer of Chinese events, a China-based Korean journalist rather than an actor on the Korean political scene. As a representative of a fellow "oppressed people"-Koreans-Sin desperately wanted China to achieve internal unity in order to successfully fight against the imperialist predations. ${ }^{10}$ The alliance with the left was a key element of the internal unity that, Sin felt, besieged China urgently needed. However, at the same time, China could serve as a useful trope for indirectly describing Korea's situation as well. Indeed, such a strategy had a history in modern Korea - already during the last precolonial decade, China was often used as a trope for alluding to Korea's own problems in the Korean press (Baik 1997). By utilizing China as an external reference, Sin Ŏnjun-while maintaining certain critical distance vis-à-vis the militant leftist radicals—was emphasizing the importance of a mass-based radical movement in an impoverished agrarian society riddled with unsolvable social conflicts and struggling against foreign oppression, be it China or the home country of Sin's Korean readers. Describing a possible alliance between the Communists and the "left-wing Guomindang" (and other "leftist nationalists") as a potential

${ }^{10}$ See, e.g., Sin Ŏnjun's article on the imperialist penetration of China and the perspectives of the Chinese resistance printed in Tong'a Ilbo on January 2, 1935 (Min 2000a, 586-89). 
recipe for a "new revolution" (see above), Sin Ŏnjun was seemingly hinting at the huge potential of a left-right alliance at home, in Korea, and among the Korean exiles abroad.

It might not be an accident that Sin's Lu Xun interview appeared in the press almost a year after it was conducted, in Tong'a Ilbo's sister monthly Sintong'a's April 1934 issue. On March 1, 1934, the representatives of both leftist and some moderate rightist Chinabased Korean anti-Japanese parties and groups_-including the Korean Independence Party - met in Nanjing and decided to strengthen their unity as parts of the united antiJapanese front. This united front, however, was not joined by the strongly anti-communist Han'guk Aeguktan 韓國愛國團 (Korean Patriotic League) of Kim Ku (1876-1949), who considered the cooperation with leftists highly undesirable (Kang 2003, 50-55). It is not impossible to assume that the publication of Lu Xun's interview was supposed to support the idea of a broad anti-colonial alliance with the leftists by emphasizing the "proletarian" sympathies of the universally respected contemporaneous Chinese writer.

"China," in a word, appears as a trope for "Korea" in Sin Ŏnjun’s writings—a foreign reference, which shared with Korea the situation of external dependence (Korea being a colony, and China being reduced to a semi-colony), internal repression, a "feudal" legacy constantly evoked by reactionary rulers, and a growing rural crisis. Discussing all these issues in the Chinese material was an expedient way to avoid colonial censorship; framing the Chinese revolution as a process with the most radical, often exceedingly violent and illiberal, leftist force - the Communists - in the center was a way to propagate the virtues of an alliance with the radicals to the readers at home while alerting Korea's nationalists to the problematic points of communist radicalism.

\section{In Place of Conclusion: Why Lu Xun Was Turned into a Revolutionary Radical}

Why then should Lu Xun be framed as a paradigmatic radical revolutionary-in a much exaggerated way compared to where he stood in reality? To be sure, it was more or less accepted in the colonial-age Korean public space that Lu Xun was a revolutionary-but more of a literary kind than a revolutionary one in the literal sense of the world. Among the colonial-era Korean writers, it was perhaps Yi Yuksa (1904-44), a noted poet and a left-nationalist revolutionary (rather close to the communist movement) who was influenced the most by Lu Xun's emphasis on individual ethical autonomy, moral courage, and the resistance spirit (Pak Sŏngch'ang 2015). Yi-who briefly met Lu Xun in Shanghai in June 1933 (Kim Hŭigon 2010, 171-77)—wrote his obituary for Chosŏn Ilbo in 1936. Yi Yuksa readily acknowledged Lu Xun as a socially engaged author, who, by describing the helplessness of contemporaneous Chinese, hoped to invigorate Chinese youth in order to build a new China, free of the delusions of "traditional" moralism or the shackles of a fatalistic worldview. At the same time, however, Yi defined Lu Xun as a peasant rather than proletarian writer, strongly emphasizing the fact that "nothing proletarian can be found in Lu Xun's writings.” After all, China remained largely a precapitalist society; Lu Xun's focus on peasants or marginalized urban dwellers was a way to develop a critical realism true to China’s particular conditions. While mentioning Lu Xun's strained relationship with Guomindang authorities, Yi also attempted to shield the writer whom he so revered from "ultra-leftist" attacks. He reminded Lu Xun's critics on the left about the efforts Lu Xun made to translate and introduce Soviet literary 
theory_without being a Communist Party member on paper (Yi Yuksa [1936] 2004, 213-21). This portrait was indeed much closer to the truth than the exaggerations that abound in Sin Ŏnjun's portrayal of the great Chinese writer. Yi's obituary indicates that knowledge of the realities of China's leftist literary movement and $\mathrm{Lu}$ Xun's place inside that movement was by no means missing in colonial-era Korea. Why then did Sin Ŏnjun need to frame Lu Xun as a proletarian revolutionary zealot?

Such a framing might have fulfilled two goals. First, firmly believing in the Chinese left's role in the struggle against "feudalism" and "fascism," Sin Ŏnjun might have aimed at utilizing a universally popular modern author, Lu Xun, as an example of an attractive and virtuous leftist (Hong 2011). After all, Lu Xun combined devotion to the radical cause with "humanist" beliefs, international appeal, and intellectual independence-the qualities many nationalists in Korea could find highly positive. To frame a world-famous modern writer as a proletarian devotee living a life of a Chinese peasant in hiding from the authorities could imply a legitimation for the radical cause, valid both for Korea's left and for the nationalist camp, something An Ch'angho's disciples would desperately need after the Singan'hoe was dissolved in 1931 due, in no small part, to leftright contradictions. The Comintern, after its radical turn in 1927-28, no longer emphasized the pan-national united front with the right as an obligatory part of the Korean communists' strategy, while communists inside Singan'hoe regarded the predominantly nationalist leadership of the organization as too moderate and too prone to compromise with the colonial authorities (Scalapino and Lee 1972, 133-34; Yi Kyunyŏng 1993, 38086). Second, ascribing to Lu Xun improbably "over-internationalist" remarks about the unimportance of the Korean language for Koreans could be a rhetorical device aimed at indirectly criticizing the "unrealistic" internationalism of the communist movement in favor of a more "realistic," down-to-earth, nationalist approach. In this way, Lu Xun's remarks—or, rather, remarks attributed to Lu Xun-were to represent what the Young Korea Academy did not wish to accept in the communist movement, while inviting all the leftists, communists included, to participate in a broad anti-imperialist collaboration.

Whether this invitation was acceptable to Korea's leftists was, of course, yet another issue. Yi Chaeyu (1905-44), an important communist organizer in Kyŏngsŏng (Seoul) in the early 1930s, is known to have considered the Young Korea Academy "paid spies of the Japanese imperialism," and this opinion seemingly had currency among the most determined communist militants (cited in Kim Kyŏng’il 2007, 130-31). Chu Yŏngha (1908-?), who was yet another important communist militant of the 1930s and would become North Korea's first ambassador to the USSR in 1949, mentioned a more generalized category of "Christians," rather than the Young Korea Academy concretely, in his 1935 pamphlet on the dangers of “Korean national reformism” (Chosŏn minjok kaeryangjuŭi 朝鮮 民族改良主義). He regarded them-as well as Ch’ŏndogyo adepts and assorted liberal nationalist journalists, including Sin Ŏnjun's employer, Tong’a Ilbo-as representatives of Korean landowning and commercial interests who did suffer from unequal competition due to the Japanese capital's penetration into Korea and Japanese colonizers' policies, but still generally had been demonstrating a tendency to join Japanese imperialism's camp in order to acquire at least a minor fraction of the profits (cited in Sin Chubaek 1987, 314-16). The attitudes decisively changed only in the late 1930s, as the creation of the anti-fascist united front became a new priority on the left. 
Sin Ŏnjun’s China reporting, carefully crafted to fit into the Young Korea Academy’s political agenda, belongs to the colonial-era tradition of China reportage that had its origins in the early 1920s. Not unlike Sin Ŏnjun himself, the Korean journalists who did the reporting on the ground in China before him were often ideologically inspired intellectuals, of either communist or nationalist (often rather radical nationalist) persuasions. Such reporting-Sin Ŏnjun's own reports included-appears to represent an important transnationalist streak in colonial-era Korea's moderate nationalist movement. As China could be used as a useful external reference to refer to while discussing the issues of concern to Korea's nationalists, its revolutionary tasks were seen as directly relevant to Koreans. Pre-1927 collaboration between the Guomindang and the Communists was seen as a blueprint for a united front of all the anti-colonial forces in Korea; after the failure of this collaboration, nationalist Korean journalists such as Yi Kwan'yong or Sin Ŏnjun were still hoping for a Guomindang turn to the left and the resumption of cooperation with the Communists for several more years.

After such hopes proved decisively ungrounded, Sin Ŏnjun started to pay closer attention to the development of the Chinese Communist movement-indeed he was one of the first Korean nationalist intellectuals to do so. It is possible that one of the reasons for his special attention towards Communist successes and failures in the Chinese countryside is related to the understanding of China as a possible model for future developments in Korea. In some ways, China, a semi-colony with a semi-fascist government unable to control its own countryside, went ahead of Korea, a colonial society tightly controlled by the Japanese army and police: there was no communist army in Korea controlling sizable chunks of the rural areas, and no Korean communist leader could earn the nickname of “Korea’s Stalin” in the way Mao Zedong might be dubbed "China's Stalin." China was the place where revolutionary developments, which were stymied by colonial oppression in Korea, could unfold in a freer way. In fact, that was the way in which China was perceived by Korea's communists. China was seen as a country where a "bourgeoisie's party" (the Guomindang) and a "working people's party" (the Communists) already became mass organizations. ${ }^{11}$ Given the attention the nationalist Korean press paid to Chinese political developments (Tikhonov 2015, 104-6), it appears that nationalists too saw the Chinese events as, at least, highly relevant to Korea's own present and future.

Learning about the Chinese revolution could be seen as helpful in formulating a vision for Korea's future. Clear knowledge of the flipside of China's revolutionary developments (the "Red terror" in the Communist-controlled areas, the inherent illiberalism of the Communist movement, etc.) could be needed to prevent the emergence of similar problems in Korea. China might be a strictly foreign country, but China's image in the Korean press, framed by the likes of Sin Ŏnjun—nationalist journalists with an agenda of their own-was a part and parcel of the domestic discursive struggles. It was a useful template needed to delineate both the potential and the dangers of the radical revolutionary developments; as such, it inspired hope and caused concern.

\footnotetext{
${ }^{11}$ See, e.g., a 1927 report by Kim Tong'u, a Korean communist, to the Comintern, comparing Chinese and Korean conditions: РГАСПИ Ф. 495. Оп. 135. Д. 146. Л. 203-14, reprinted in Shirinya and Wada (2007).
} 
The coverage of a foreign issue framed in a way that is calculated to influence the national debate on a domestic issue is a known phenomenon in media theory; in most cases, however, it is the established elites that are assumed to manipulate public opinion by framing the foreign news in the ways suited to their purposes. ${ }^{12}$ The case of Sin Ornjun provides, on the contrary, a fascinating example of how an anti-colonial nationalist attempted to frame foreign news in a particular way in order to advance the cause of anti-imperialist unity across the ideological and political spectrum. It demonstrates how perceptions of the foreign Others were subordinated to national concerns in colonial-age Korea, and reveals the mechanisms through which public opinion on foreign and domestic issues was formed inside the colony's public space.

\section{Acknowledgments}

I am truly grateful to Konrad Lawson (University of St Andrews), who was generous enough to edit this article and suggest a number of revisions. I would like to express my deep appreciation to three anonymous readers whose thoughtful, detailed, and critical comments helped me to greatly improve this article. The encouragement and interest of Professor Jeffrey Wasserstrom, the editor of the Journal of Asian Studies, was of great help in the course of revisions. The original version of this article was presented at the seminar on internationalism in modern East Asia co-sponsored by Oslo University and Saitama University (March 14, 2016). I would like to offer belated thanks to all its participants for their insightful comments on this paper. The research that led to the publication of this paper has been generously supported by the Department of Culture Studies and Oriental Languages (Oslo University) and the Institute of Humanities (Seoul National University). The latter provided me with the status of visiting researcher and access to the library of Seoul National University, which was of enormous importance for my research work.

\section{List of References}

An PyŏngjıK, ed. 1979. Sin Ch’aeho. Seoul: Han'gilsa.

BAIK, Young-SEo. 1997. “Taehan Cheguk ki Han'guk Ôllon ŭi Chungguk Insik” [Korean Media’s Consciousness of China in the Period of the Taehan Empire]. Yǒksa Hakpo 153:105-39.

Chang TŏKchun. 1920. “Tongnan ŭi Pukkyŏng Esŏ” [From War-Ridden Beijing]. Tong’a Ilbo, August 8-27.

Сно̆N MүŏNghyŏк. 2006. 1920 Nyŏndae Han'guk Sahoejuŭi Undong Yŏn'gu [Research on the Korean Socialist Movements of the 1920s]. Seoul: Sŏn'in.

Chosŏn Ilbo SARYo Yŏn’gusil, ed. 2004. Chosŏn Ilbo Saram Dŭl. Ilche Sidae P’ŏn [Chosŏn Ilbo's People: Japanese Colonial Period]. Seoul: Random House-Chungang.

Chu Yohan. 1928. "Chungguk Kungmin Undong ŭi Kaegwan” [An Outline of China's National Movement]. Tong’a Ilbo, January 1.

\footnotetext{
${ }^{12}$ See, e.g., Entman (2004) on how the framing of the foreign news in the United States influences domestic debates and perceptions.
} 
Davies, Gloria. 2013. Lu Xun's Revolution: Writing in a Time of Violence. Cambridge, Mass.: Harvard University Press.

DirLiK, ArIF. 1975. "The Ideological Foundations of the New Life Movement: A Study in Counterrevolution.” Journal of Asian Studies 34(4):945-80.

Entman, Robert M. 2004. Projections of Power: Framing News, Public Opinion, and U.S. Foreign Policy. Chicago: University of Chicago Press.

Feuerwerker, Yi-Tsi Mei. 1982. Ding Ling’s Fiction: Ideology and Narrative in Modern Chinese Literature. Cambridge, Mass.: Harvard University Press.

Goodman, Bryna. 1995. Native Place, City, and Nation: Regional Networks and Identities in Shanghai, 1853-1937. Berkeley: University of California Press.

Han KinyŏNG. 2005. “Kŭndae Ch'ogi Han'gug’in ŭi Tong’asia Insik” [Koreans' Views on East Asia in the Early Modern Period]. Taedong Munhwa Yŏn'gu 50:167-98.

Hong SŏKP’Yo. 2008. “No Sin ŭi Singminji Chosŏn Insik e Kwanhan Yŏn'gu” [Study of Lu Xun's Perceptions of Colonial Korea]. Chungguk Ŏmunhakchi 26:143-74.

. 2011. "Lu Xun kwa Sin Ônjun, Kŭrigo Karashima Takeshi” [Lu Xun, Sin Ônjun, and Karashima Takeshi]. Chungguk Munhak 69:133-55.

Hu Minghui. 2015. China's Transition to Modernity: The New Classical Vision of Dai Zhen. Seattle: University of Washington Press.

Hu SHI. 1925. "Ho Chŏk Ch’uksa” [Hu Shi’s Congratulatory Greetings]. Tong’a Ilbo, January 1.

HŭngSadan. 1929. "Report on the Situation after the Far Eastern Conference" [Wŏndong Taehoe Chŏnghyŏng Pogo ŭi Kŏn]. Document No. 211. September 13. Preserved by Hŭngsadan Ponbu (Young Korea Academy Headquarters).

Kang Man’GIL. 2003. Chosŏn Minjok Hyŏngmyŏngdang kwa T'ongil Chŏnsŏn [The Korean National Revolutionary Party and the United Front]. Seoul: Yŏksa Pip’yŏngsa.

Kim Chun’yŏp and Kim Changsun. 1986. Han'guk Kongsanchuŭi Undongsa [The History of the Korean Communist Movement]. Vols. 1-5. Seoul: Ch’ŏnggye Yŏn'guso.

KIm HŭIgOn. 2010. Yi Yuksa P’yŏngjŏn [The Commentary Biography of Yi Yuksa]. Seoul: P’urŭn Yŏksa.

Kim KYŏng’il. 2007. Yi Chaeyu-Na ŭi Sidae, Na ŭi Hyŏngmyŏng [Yi Chaeyu-My Epoch, My Revolution]. Seoul: P’urŭn Yŏksa.

Kim Minhwan, Pak Yonggyu, and Kim Munjong. 2008. Ilche Kangjŏmgi Ŏllonsa Yŏn'gu [Research on the (Korean) Media History during the Japanese Colonial Period]. Seoul: Nanam.

KIм SEHO. 1999. “1920 Nyŏndae Han'guk Ôllon ŭi Chungguk Kungmin Hyŏgmyŏng e Taehan Panŭng-Tong’a Ilbo T'ŭkp'awŏn Chu Yohan ŭi Sinchungguk Pangmungi Ch’wijae (1928.10-1929.1) Rŭl Chungsim Ǔro" [The Korean Reactions to the Chinese Nationalist Revolution in the 1920s-Focused on the Report by the Tong'a Ilbo Correspondent, Chu Yohan, Records of (My) Visit to New China (1928.10-1929.1)]. Chungguk Hakpo 40:411-29.

. 2014. "Pukpŏl Chikhu 'Sinhŭng Chung’guk' e Taehan Han'guk Ŏllon ŭi il Sigak” [One View on "New China" after the Northern Expedition by the Korean Press]. Chung’guk Kŭnhyŏndaesa Yŏngu 61:73-117.

Kim Sijun. 1997. “No Sin i Mannan Han'guk'in” [Koreans Whom Lu Xun Met]. Chungguk Hyŏdae Munhak 13:127-63.

. 2002. "Sin Ŏnjun ŭi ‘No Sin Pangmun'gi' e Taehaesŏ” [On Sin Ŏnjun’s “Record of a Visit to Lu Xun”]. Chungguk Hyŏndae Munhak 22:1-24. 
Kim Tongmyŏng. 2005. Chibae wa Chŏhang, Kŭrigo Hyŏmnyŏk [Domination, Resistance, and Cooperation (in Colonial-era Korea)]. Seoul: Kyŏngin Munhwasa.

Lee, Feigon. 1983. Chen Duxiu, Founder of the Chinese Communist Party. Princeton, N.J.: Princeton University Press.

Liu Yunfeng, ed. 2001. Lu Xun Yiwen Quanji [Lu Xun’s Unpublished Writings]. Vols. 12. Beijing: Qunyan Chubanshe.

Lu Xun. 1981. Lu Xun Quanji [Complete Works by Lu Xun]. Vols. 1-16. Beijing: Renmin Wenxue Chubanshe.

Min Tu-KI, ed. 2000a. Sin Ŏnjun Hyŏndae Chunggul Kwan'gye Nonsŏlsŏn [Selected Writings by Sin Ŏnjun on Modern China]. Seoul: Munhak kwa Chisŏngsa.

, ed. 2000b. "Sin Ŏnjun kwa Kŭ ŭi Chungguk Kwan'gye Nonsŏl e Taehayŏ” [On Sin Ŏnjun and His China-Related Writings]. In Sin Ŏnjun Hyŏndae Chunggul Kwan'gye Nonsŏlsŏn [Selected Writings by Sin Ŏnjun on Modern China], ed. Min Tu-ki, 13-21. Seoul: Munhak kwa Chisŏngsa.

Pak Ch’ansŭNg. 2006. Minjokchuŭi Sidae: Ilche ha ŭi Han'guk Minjokchuŭi [The Nationalism Era: Korean Nationalism under Japanese Imperial Rule]. Seoul: Kyŏngin Munhwasa.

Pak Sŏngch’Ang. 2015. “Han-Chung Kŭndae Munhak Pigyo ŭi Chaengchŏm: Yi Yuksa ŭi Munhakchŏk Mosaek kwa Lu Xun" [The Discussion Points of the Comparisons between the Modern Literatures of China and Korea: Yi Yuksa’s Literary Quests and Lu Xun]. Comparative Korean Studies 23(2):167-209.

Pak Yonggyu. 2015. Singminji Sigi Ŏllon kwa Ŏllon'in [Media and Journalists of the Colonial Period]. Seoul: Somyŏng.

Reese, Stephen D. 2001. "Prologue-Framing Public Life: A Bridging Model for Media Research.” In Framing Public Life: Perspectives on Media and Our Understanding of the Social World, eds. Stephen D. Reese, Oscar H. Gandy, and August E. Grant, 7-32. Mahwah: N.J.: Lawrence Erlbaum Associates.

Robinson, Michael. 1984. "Colonial Publication Policy and the Korean Nationalist Movement.” In The Japanese Colonial Empire, 1895-1945, eds. Ramon H. Myers and Mark R. Peattie, 312-43. Princeton, N.J.: Princeton University Press.

Scalapino, Robert A., and Lee Chong-Sik. 1972. Communism in Korea: The Movement. Berkeley: University of California Press.

Sheng Yue. 2009. Universitet Imeni Syn Yat-sen'a v Moskve i Kitaiskaya Revolutsiya. Vospominaniya [The Sun Yat-sen University in Moscow and the Chinese Revolution: Memoirs]. Moscow: Kraft Publishers.

Shi Qı. 2011. "Lu Xun Wannian de Jingji Zhuangkuang-Du Lu Xun Shuxin Zhaji” [Lu Xun's Economical Circumstances in the Last Years of His Life-Reading Lu Xun's Letters]. Bainian Chao 10:70-73.

Shirinya, Kirill, and Haruki Wada, eds. 2007. VKP(B), Komintern i Koreya, 1918-1941

[All-Russian Communist Party of Bolsheviks, Comintern and Korea, 19181941]. Moscow: ROSSPEN.

Sim ChiYŎN. 2015. Chosŏn Kongsanjuŭija Tŭr ŭi Ŭisik kwa Nolli [The Consciousness and Logic of the Korean Communists]. Seoul: Paeksan Sŏdang.

Sin Chubaek. 1987. 1930nyŏndae Minjok Haebang Undongnon Yŏn'gu [The Research on the (Korean) National Liberation Movement Debates in the 1930s]. Vol. 1. Seoul: Saegil.

SIN Ŏnjun. 1925. "In’gyŏk kwa Kyoyuk” [Personality and Education]. Tong’a Ilbo, March 27-April 6. 
(assumed authorship). 1929. "Nonong Chŏngch’i Silsi Mo T’aekdong Kun Sosik" [The News on Mao Zedong's Army and (Its) Practicing of Workers' and Peasants' Policies]. Tong'a Ilbo, October 6.

(assumed authorship). 1931a. "Kongsan'gun ŭi Chinsang. 'Ssobiet’ǔ Kuyŏk ŭi Sanghwang" [The Real Appearance of the Communist Army: The Situation in the "Soviet" Areas]. Tong'a Ilbo, July 8.

(assumed authorship). 1931b. "Puhŭng Tojung ŭi Sin T'oigi: Hyŏngmyŏng Kyŏngkwa wa Sinkŏnsŏl ŭi Kŭnhwang” [New Turkey’s Renaissance: The Revolutionary Events and the Update on the New Construction]. Tonggwang 27:24-28.

(assumed authorship). 1934. "Chungguk Taemunho No Sin Pangmungi” [The Record of (My) Visit to Lu Xun, China’s Great Writer]. Sintong’a 4:29-31.

Tien Hung-MaO. 1972. Government and Politics in Kuomintang China, 1927-1937. Stanford, Calif.: Stanford University Press.

Tikhonov, Vladimir. 2015. Modern Korea and Its Others: Perceptions of the Neighbouring Countries and Korean Modernity. London: RoutledgeCurzon.

Yang, Benjamin. 1990. From Revolution to Politics: Chinese Communists on the Long March. Boulder, Colo.: Westview Press.

Yı HyŏnhŭI. 1992. Cho Tongho Hang’il T’ujaengsa [The History of Cho Tongho's AntiJapanese Struggle]. Seoul: Ch’ŏnga Ch'ulp'ansa.

Yı Hyŏnju. 2003. "Ilcheha [Suyang] Tong'uhoe ŭi Minjok Undonnon kwa Sin'ganhoe" [The National Movement Vision of the Friendly Society for Self-Cultivation in the Japanese Colonial Period and Sin'ganhoe]. Chŏngsin Munhwa Yŏn'gu 26(3): 185-209.

YI KWAN’YONG. 1928a. "Hyŏngmyŏng Wansŏngtoen Chungguk ŭl Hyanghamyŏnsŏ" [Towards the Completion of the Revolution in China]. Chosŏn Ilbo, October 20.

_ _ 1928b. "Kyŏngsi Haji Mothal Ilp’a” [A Faction Not to Be Discarded]. Chosŏn Ilbo, December 6.

Yi Kyunyŏng. 1993. Sin'ganhoe Yŏn'gu [Research on Sin’ganhoe]. Seoul: Yŏksa Pip’yŏngsa.

Yi Myŏnghwa. 2002. Tosan An Ch'angho ŭi Tongnip Undon kwa T'ong’il Nosŏn [Tosan An Ch'angho's Independence Movement and the (Movement) Unification Line]. Seoul: Kyŏngin Munhwasa.

Yi Paeno. 2002. Chu Yohan Yón'gu [Studies on Chu Yohan]. Seoul: Tonggwang Munhwasa.

Yi Yuksa. [1936] 2004. “No Sin Ch’udomun” [Obituary for Lu Xun]. In Yi Yuksa Chŏnjip [Complete Works by Yi Yuksa], 207-21. Seoul: Kip’ŭn Saem.

Zarrow, Peter. 2005. China in War and Revolution, 1895-1949. London: RoutledgeCurzon.

Zhang Junmai. 1924. “Insaenggwan” [Views of Human Life]. Translated by Sin Ŏnjun. Tong’a Ilbo, December 29. 